\title{
Vohwinkel syndrome, ichthyosiform variant - by Camisa - Case report ${ }^{*}$
}

Síndrome de Vohwinkel, variante ictiosiforme - de Camisa - Relato de caso

\author{
Liliam Dalla Corte ${ }^{1}$ \\ Gerson Vetoratto ${ }^{2}$
}

\author{
Mariana Vale Scribel da Silva ${ }^{1}$ \\ Raquel Bissacotti Steglich ${ }^{3}$
}

\author{
Carina Flores de Oliveira ${ }^{1}$ \\ Josiane Borges ${ }^{4}$
}

DOI: http://dx.doi.org/10.1590/abd1806-4841.20132135

\begin{abstract}
Vohwinkel syndrome or keratoderma hereditaria mutilans is a rare autosomal dominant palmoplantar keratosis, which manifests in infants and becomes more evident in adulthood. Its mode of inheritance is autosomal dominant with mutation in loricrin and Connexin 26 genes. Patients with this mutation present hyperkeratosis of the palms and soles, constricting bands of the digits, usually on the fifth, and starfish-shaped hyperkeratosis on the dorsal aspects of the hands and feet. The disease mostly occurs in white women, where constricting fibrous bands appear on the digits and can lead to progressive strangulation and auto-amputation (pseudo-ainhum).The authors report a rare case of a patient with a clinical ichthyosiform variant of Vohwinkel syndrome. Keywords: Dyskeratosis congenita; Finger injuries; Hand dermatoses; Ichthyosis; Keratoderma, palmoplantar
\end{abstract}

Resumo: A síndrome de Vohwinkel ou queratodermia hereditária mutilante é uma queratose palmo-plantar rara, autossômica dominante, que se manifesta em crianças e se torna mais evidente na vida adulta. Seu modo de herança é autossômica dominante com mutação na loricrina e no gen da Conexina 26. Os pacientes com esta mutação apresentam hiperqueratose das palmas das mãos e plantas dos pés, com bandas constritivas dos dígitos, normalmente no quinto dedo e hiperqueratose em forma de estrela do mar nas regiões dorsais das mãos e dos pés. A doença ocorre principalmente em mulheres brancas, onde as bandas constritivas fibrosas aparecerem nos dígitos e podem levar ao estrangulamento progressivo e auto-amputação (pseudo-ainhum). Os autores relatam o caso de uma variante ictiosiforme da síndrome de Vohwinkel.

Palavras-chave: Ceratodermia palmar e plantar; Dermatoses da mão; Disceratose congênita; Ictiose; Traumatismos dos dedos

\section{INTRODUCTION}

Vohwinkel syndrome is a palmoplantar keratosis inherited in an autosomal dominant fashion caused by mutations in the connexin 26 gene. ${ }^{1,2}$ It is characterized by honeycombed, palmoplantar keratosis, transgredient and mutilating, which manifests in early childhood. ${ }^{1,3}$ Constricting fibrous bands on the digits (pseudo-ainhum), mainly on the fifth finger, can lead to progressive autoamputation. ${ }^{3}$ In combination with starfish-shaped keratoses over the elbows, knees, wrists and knuckles as well as sensorineural hearing loss are characteristic features. ${ }^{4}$ Nail dystrophy, alopecia, onychogryphosis and a variety of neurological abnormalities may also occur. ${ }^{3}$ In Camisa's variant, the mutation occurs in loricrin, which is responsible for the cornification regulation. In this, the palmoplantar keratoderma is diffuse and pseudoainhum can also manifest. ${ }^{3}$ However, there is moderate, generalized congenital ichthyosiform dermatosis, but no association with hearing loss. No consistent extracutaneous characteristics were found. ${ }^{4}$

Approved by the Advisory Board and accepted for publication on 04.12.2012

* Work performed at the Dermatology Service, Santa Casa de Misericórdia de Porto Alegre - Porto Alegre (RS), Brazil.

Conflict of interest: None

Financial funding: None

MD, Dermatologist, Dermatology Service at Santa Casa de Misericórdia de Porto Alegre - Porto Alegre (RS), Brazil.

MD, Dermatologist/Mycologist - Preceptor of the Dermatology Service at Santa Casa de Misericórdia de Porto Alegre - Porto Alegre (RS), Brazil.

MD, Dermatologist at Santa Casa de Misericórdia de Porto Alegre-Porto Alegre(RS), Brazil.

MD, Pathology Resident Physician at Santa Casa de Misericórdia de Porto Alegre - Porto Alegre (RS), Brazil. 


\section{CASE REPORT}

A 52-year-old healthy woman, sought assistance for thickened palms and soles which began in her childhood, as well as changes in one of her toes, which began a few years ago. She was the third of five generations involved. Her mother had a finger amputated due to the evolution of the same disease. Physical examination detected transgredient, diffuse palmoplantar hyperkeratosis, with constrictive bands on the fifth toe (left) (pseudo-ainhum) - generalized ichthyosiform dermatosis with no hearing loss (Figures 1, 2 and 3). Anatomopathological examination of the palmar region found hyperkeratosis with orthokeratosis and parakeratosis (Figures 4).

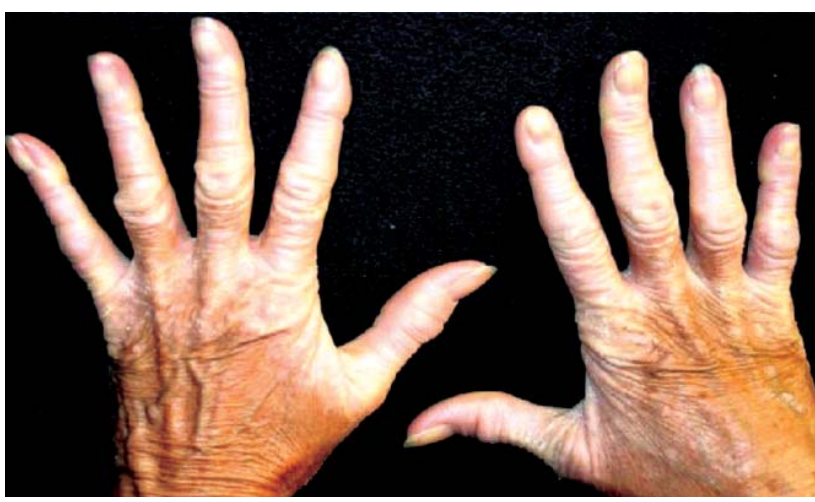

FIGURE 1: Transgredient palmoplantar hyperkeratosis

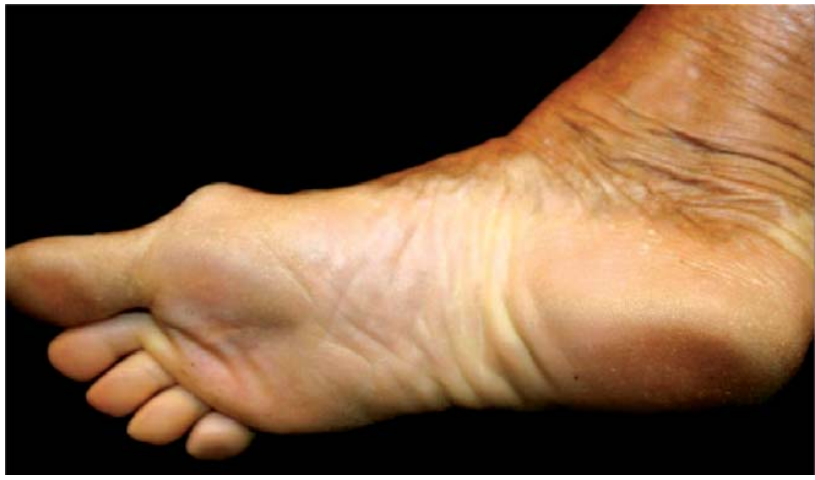

FIGURE 2: Transgredient plantar hyperkeratosis

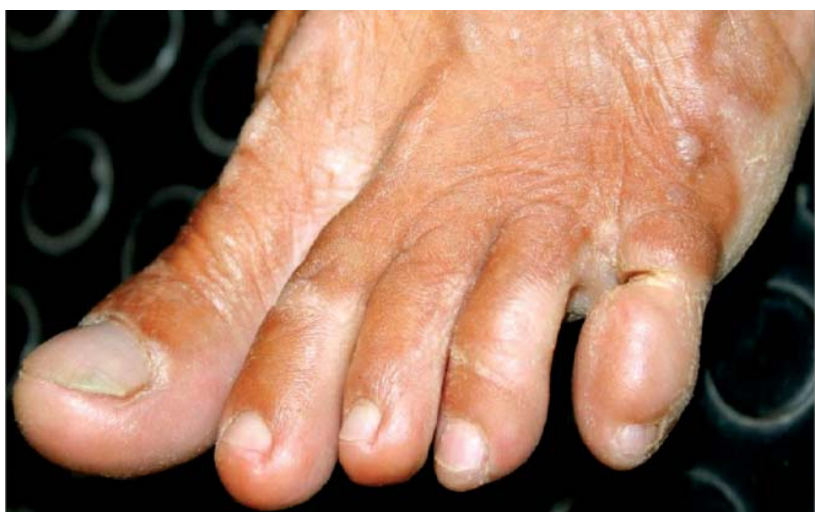

FIGURE 3: constrictive bands on the fifth toe (pseudo-ainhum)

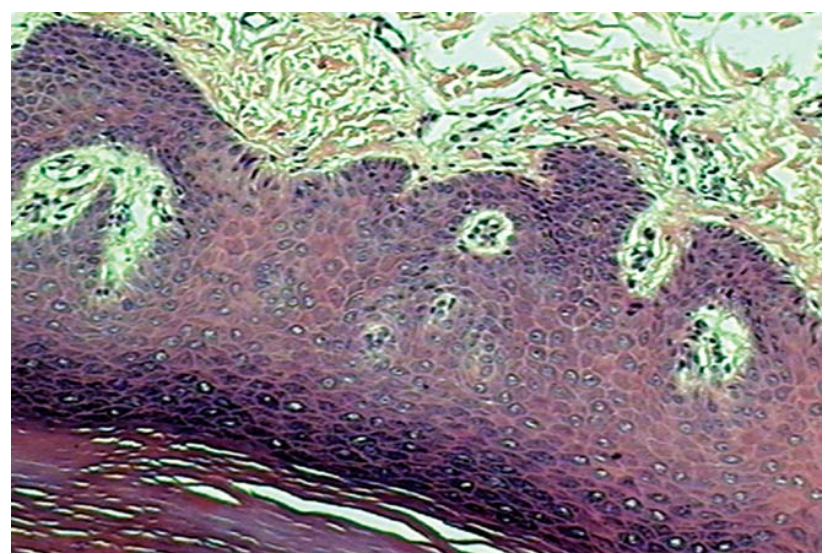

FIGURE 4: Anatomopathological examination of the palmar region: Hyperkeratosis with orthokeratosis and parakeratosis

\section{DISCUSSION}

Vohwinkel syndrome is a rare autosomal dominant palmoplantar keratoderma, with approximately 50 cases reported in the literature, which manifests in childhood and becomes more evident in adulthood. ${ }^{5}$ This disease mostly occurs in white women. The diagnostic features of Vohwinkel syndrome (SV) include: starfish-shaped palmoplantar hyperkeratosis, constricting bands on the digits of the hands or feet and starfish-shaped hyperkeratosic lesions, salmon-colored or articular cushion on the dorsum of the hands. ${ }^{1,3}$ Nail dystrophy, alopecia, onychogryphosis and a variety of neurological abnormalities may also occur. ${ }^{4}$ There is an association between ichthyosis and deafness, which allows the syndrome to be classified into two variants: (1) an ichthyosis-associated variant (OMIM 604117) and a (2) deafness-associated variant (OMIM 124500). 6 The variant with ichthyosis, also called Camisa's variant, is characterized by the loricrin mutation. This protein is synthesized in the granular layer; it migrates to the cell periphery, where it is deposited beneath the plasma membrane. It links to several other proteins, forming a cornified cell envelope. Thus, it promotes an effective barrier between the body and the environment. ${ }^{7}$ This mutation presents a palmoplantar keratoderma, generalized thin desquamation on the extensor surfaces of the finger joints, and constricting bands around the digits (pseudo-ainhum). ${ }^{1,3,4}$ Abnormal structure of the stratum corneum is an important pathophysiological feature, in which the affected skin presents an increased loss of water, reduction of cell cohesion and increased skin fragility. ${ }^{78}$ The case reported fulfills all the clinical features of the SV ichthyosis variant. The treatment is very difficult and tends to be symptomatic: keratolytic agents and systemic retinoids are used for the treatment of hyperkeratosis, but without consistent results. ${ }^{6,9}$ Reconstructive surgery is used to treat pseu- 
do-ainhum. Excision of the constricting bands, the use of grafts and flaps have been an alternative to hyperkeratosis and autoamputation of the digits. ${ }^{9}$ The differential diagnosis of Vohwinkel's syndrome includes other types of keratoderma that can be associated with auto-amputation of the digits: Olmsted syndrome, acral keratoderma, congenital pachyonychia, Sybert's palmoplantar keratoderma, Meleda disease and Gamborg-Nielsen palmar and plantar keratoderma. ${ }^{8}$ Other non-hereditary diseases that may cause constricting bands with or without hyperkeratosis include: leprosy, tertiary syphilis, frambesia, ainhum, scleroderma, amniotic bands, ergotamine poisoning, spinal medulla tumors, Reynold's syndrome, breast cancer and syringomyelia among others. ${ }^{8}$

\section{REFERENCES}

1. Krol LA, Siegel D. Keratodermas. In: Bolognia LJ, Jorizzo LJ, Schaffer JV, editors. Dermatology. 3rd ed. New York: Elsevier; 2012. p. 877-8.

2. Seirafi H, Khezri S, Morowati S, Kamyabhesari K, Mirzaeipour M, Khezri F. A new variant of Vohwinkel syndrome: a case report. Dermatol Online J. 2011;17:3.

3. Kelsell PD, Leigh Ml. Inherited Keratodermas of palms and soles. In: Wolff K, Goldsmith LA, Katz SI, Gilchrest BA, Paller AS, Leffell DJ, editors. Fitzpatrick's dermatology in general medicine. 7th ed. New York: Mc Graw Hill; 2008. p. 428.

4. Judge MR, Mc Lean WHI, Munro CS. Disorders of keratinization. In: Burns T, Breathnach S, Cox N, Griffths C, editors. Rook's textbook of dermatology. 8th ed. Chichester: Wiley-Blackwell; 2010. p. 19.98

5. Sinha M, Watson SB. Keratodermia hereditarium mutilans (Vohwinkel syndrome). J Hand Surg Eur Vol. 2009;34:235-7.

6. O'Driscoll J, Muston GC, McGrath JA, Lam HM, Ashworth J, Christiano AM. A recurrent mutation in the loricrin gene underlies the ichthyotic variant of Vohwinkel syndrome. Clin Exp Dermatol. 2002;27:243-6.

7. Schmuth M, Fluhr JW, Crumrine DC, Uchida Y, Hachem JP, Behne M, et al. Structural and functional consequences of loricrin mutations in human loricrin keratoderma (Vohwinkel syndrome with ichthyosis). J Invest Dermatol. 2004;122:909-22.

8. Cavalcante, LIS; Holanda, EM; Almeida, TLP; Filho, JWA. Vohwinkel's mutilating keratoderma: report of three familial cases An Bras Dermatol. 2003;78: 311-8.

9. Bassetto F, Tiengo C, Sferrazza R, Belloni-Fortina A, Alaibac M. Vohwinkel syndrome: treatment of pseudo-ainhum. Int J Dermatol. 2010;49:79-82.

\author{
MAILING ADDRESS: \\ Liliam Dalla Corte \\ Recepção 4- Dermatologia \\ Rua Prof. Annes Dias, 295 - Centro \\ 90020-090 - Porto Alegre - RS \\ Brazil \\ E-mail:ldcorte2009@gmail.com
}

How to cite this article: Corte LD, Silva MVS, Oliveira CF, Vetoratto G, Steglich RB, Borges J. Vohwinkel syndrome, variant ichthyosiform- by Camisa - Case report. An Bras Dermatol. 2013;88(6 Suppl 1):S206-8. 